\title{
Does Human Resource Management Practices Moderate The Relationship Between Nepotism and Attitude?
}

\author{
Mahdani Ibrahim ${ }^{1 *}$, Maulana Alimin ${ }^{2}$, and Banta Karollah ${ }^{3}$ \\ ${ }^{1}$ Universitas Syiah Kuala, Banda Aceh, Indonesia \\ ${ }^{2}$ General Hospital Dr. Zainoel Abididin, Banda Aceh, Indonesia \\ ${ }^{3}$ Sabang College of Economics, Banda Aceh, Indonesia
}

\begin{abstract}
This study aims to examine the moderating effect of human resource management practice (HRMP) variables on the relationship between nepotism variables and attitude variables (job satisfaction, organisational citizenship behaviour $(O C B)$ and organisational commitment).A research sample of 300 workers in the three largest hospitals in Aceh (Dr. Zainoel Abidin General Hospital, Meuraxa General Hospital and Harapan Bunda Hospital). Primary data were obtained by distributing questionnaires to participants in the three hospitals with 100 questionnaires each.Data were analysed using simple regression and moderated regression analysis. The results of our analysis found that HRMPs have a moderating effect on the relationship between nepotism and job satisfaction and nepotism and organisational commitment.The moderating effect of HRMPs was not found in the relationship between nepotism and $O C B$.
\end{abstract}

Keywords: HRMPs, Job Satisfaction, OCB, Organisational Commitment, Nepotism.

\section{Introduction}

Nepotism has developed throughout the world for generations. Although some researchers believe that nepotism has declined with the development of giant companies, some believe that nepotism is still alive and thriving (Sarpong \& Maclean, 2015).Nepotism, the human tendency to provide protection or provide assistance to family, friends and relatives, who have no achievements that qualify, has been described in contemporary social life as opposed to natural justice, social justice and counterproductive to successful organisation (Billet, 2009; Stewart, 2003).

Nepotism is often prevalent in businesses run by families who are also the owners of the company (Lubatkin et al., 2015). In Indonesia, the practice of nepotism does not only occur in family companies but also in public organisations, both profitoriented and non-profit oriented, and the practice of nepotism has worsened economic conditions due to low competitiveness (Malik, 2018).

In hospitals, we often observe the practice of nepotism in the recruitment procedure of medical personnel and non-medical employees and even in acquiring a good position in the organisational structure. The practice of nepotism can also be considered a part of a resource package that shows that business families can negotiate with their relatives (Lubatkin et al., 2015).A review ofmany areas of responsibility for personnel managerssurprisingly showsthat some researchers have raised great concern about nepotism, but our literature search shows that very little empirical research has been carried out in this field.

A number of highlights have also focused on the negative aspects of nepotism (Elbaz, Haddoud, \& Shehawy, 2018). Nepotism and cronyism can be seen as forms of corruption because they involve abuse of power (Hudson \& Claasen, 2017). Nepotism is an unprofessional phenomenon that benefits only family members or close friends (Arasli, Bavik,\& Ekiz, 2006).However, Jaskiewicz and Luchak (2013)had another

* Corresponding author. Email address: mahdani@unsyiah.ac.id 
view, that is, nepotism can take several forms and exist at various levels within a company, for the purpose of a conceptual framework that is better to use a dichotomous conceptualisation of the construct that defines nepotism as recruitment family managers in the top management team of a family company, and such reasons are in line with perspectives (Hambrick \& Mason, 1984).

We strongly support perspectives (Jaskiewicz \& Luchak, 2013; Hambrick \& Mason, 1984), and we work hard to re-examine nepotism because we believe that human resource management practices (HRMPs) can strengthen nepotism relationships, especially towards job satisfaction, organisational citizenship behaviour $(\mathrm{OCB})$ and organisational commitment.

\section{Literature Review and Hypotheses Development}

\subsection{Nepotism and Job Satisfaction}

When an organisation chooses a family or close friend to occupy a certain position in the organisation, such conditions are known as 'nepotism', even though the people who are placed in that position do not have adequate abilities. In this study, nepotism is defined as utilising the influence of family or relatives to achieve organisational goals. Nepotism means choosing family members or close friends based on relationships, not based on ability,which is considered a bad practice in the organisation.Nickson (2013) argued that poor labourpractices remain prevalent in the tourism and hospitality sector. Elbaz, Haddoudand Shehawy (2018) found that the practice of nepotism has a direct negative effect on several competencies (selfcompetence, team competences and change competence).

Job satisfaction is one of the main work attitude components. When people talk about employee attitudes, it usually means job satisfaction, which reflects positive feelings about a job, and results from evaluating its characteristics. Someone with a high level of job satisfaction holds positive feelings about their work, whereas people with low levels hold negative feelings (Robbins \& Judge, 2013: 74). Thus, when the practice of nepotism increases in an organisation, not all employees in the organisation feel satisfied working. Therefore, the results of research by Arasli, Bavik and Ekiz, (2006) found that nepotism has a negative effect on job satisfaction. Nepotism also negatively affects performance (Elbaz, Haddoud, \& Shehawy, 2018).From the results of the literature review above, we state the following hypothesis:

H1: HRMPs have a moderating effect on the relationship between nepotism and job satisfaction.

\subsection{Nepotism and OCB}

If nepotism has a negative impact on job satisfaction (Arasli, Bavik,\& Ekiz, 2006), then it will also have a negative impact on OCB. Work attitude is conceptually and empirically related to OCB (Bowling, Wang, \&Li, 2012).Specifically, according to Dalal (2005), employees who have a positive work attitude are expected to provide a pleasant work environment and be involved in OCB.

OCB is 'positive, pro-social, and extra-role worker behaviour that promotes the effective functioning of an organization'(Brenner et al., 2010; Luthans, 2011: 149). In this study, OCB is a positive behaviour shown by an employee and does not conflict with organisational systems that can improve the effective functioning of the organisation.OCB consists of helpful behaviours and organisational compliance (Podsakoff et al., 2000). Helpful behaviours refer to employees' voluntary efforts to help others or to prevent problems related to the work of their coworkers. Some researchers have concluded thata positive correlation exists between OCB and job satisfaction (Netemeyer et al., 1997; Foote \& Li-Ping Tang, 2008; Shafazawana et al., 2016; Xie et al., 2017).From the results of the literature review above, we state the following hypothesis: 
H2: HRMPs have a moderating effect on the relationship between nepotism and $O C B$.

\subsection{Nepotism and Organisational Commitment}

Nepotism is not good for large-scale business organisations but good for smallscale business organisations that belongto a certain family (Hayajenh, Maghrabi, \& AlDabbagh, 1994).Therefore, when viewed from an organisational aspect, the practice of nepotism is considered to not have a significant effect on organisational commitment. Organisational commitment is included in one component of work attitude (Robbins \& Judge, 2013: 79).

According to Allen and Meyer (1990), organisational commitment as a psychological relationship between an employee and an organisation makes it less likely that the employee will leave on his own volition.Meanwhile, according to Luthans (2011: 147), organisational commitment is a strong desire to remain as a member of a particular organisation, a willingness to exert a high level of effort on behalf of the organisationand a certain belief of acceptance, values and organisational goals.

In this study, organisational commitment is an emotional attachment, identification and involvement of individuals with the organisation and the desire to remain a member of that organisation. We assume that the higher the practice of nepotism, the higher the tendency for the organisational commitment to decrease. Furthermore, employees who are not committed and less loyal to the organisation will tend to show a lower level of attendance at the workplace (Pohl \& Paillé, 2011).From the results of the literature review above, we state the following hypothesis:

H3: HRMPs have a moderating effect on the relationship between nepotism and organisational commitment.

\subsection{HRMPs}

According to Sun, Aryee and Law (2007),HRMPs are holistic practices that can improve staff skills, encourage employee participation and voice in decision making and increase motivation to conduct policies, which collectively influenceorganisational performance and sustainable competitive advantage.Furthermore, Arasli, Bavik and Ekiz, (2006) highlighted that human resource management (HRM) must be practised to increase employee competency in accordance with organisational goals. HRMPs are very important in an organisation; these activities include recruitment, selection, training, career development, compensation and performance appraisal (Arasli, Bavik,\& Ekiz, 2006; Tsaur \& Lin, 2002; Reid et al., 2002).

Mondy and Martocchio (2016)also stated that HRM is utilising employees to achieve organisational goals. HRMPs are the main HRM functions that consist not only of training and development but also career planning and development activities (Mondy \& Martocchio, 2016: 25).Furthermore, Arasli, Bavik and Ekiz (2006) found that the practice of nepotism has a significant negative effect on HRM and that HRM has a significant positive effect on job satisfaction.Find1klı, Yozgat and Rofcanin (2015) found that HRMPs have a positive effect on organisational innovation and knowledge management capacity.

This study aims to identify the moderating effect of HRMPs on the relationship between the practice of nepotism and job satisfaction, organisational citizenship and organisational commitment. On the basis of the literature review, we developed a research framework, as shown in Figure 2. 


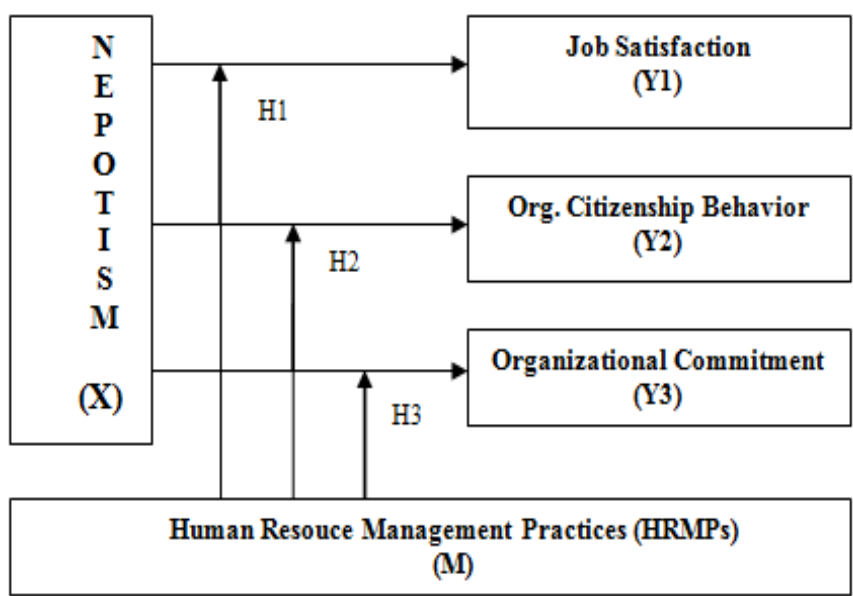

Figure 1 Research and Analysis Framework

\section{Methodology}

\subsection{Data Collection and Samples}

The data for this study were obtained from the three largest public hospitals in Aceh Province (two governmentowned and one private), with a total respondentsample of 300 medical and non-medical employees. Primary data were obtained by distributing questionnaires. The characteristics of the respondents are as follows: $45 \%$ men and $55 \%$ women, average age of 37 years and average length of work of 13 years.

\subsection{Data Analysis}

The hypotheses were tested using moderated regression analysis (MRA)(Cohen et al., 2003). Based on the MRA, three regression equations are considered:

$$
\begin{aligned}
& Y=a+b 1 X 1+e \\
& Y=a+b 1 X 1+b 2 M+e \\
& Y=a+b 1 X+b 2 M+b 3 X 1 M+e
\end{aligned}
$$

Where $Y$ is the dependent variable, $X$ is the independent variable and $M$ is the moderation variable. Sharma et al. (1981) said that $M$ can be considered a pure moderator if Equations (1) and (2) are similar but different from Equation (3), that is, $\mathrm{b} 2 \neq 0$ but $\mathrm{b} 3 \neq 0$. However, if $\mathrm{b} 2 \neq \mathrm{b} 3 \neq 0$, then $M$ is referred to as a quasi-moderator. Such variables are both a predictor and a moderator. The analysis was performed using Statistical Package for Social Science20.

\subsection{Measurement}

Nepotism is defined as utilising the influence of family or relatives to achieve organisational goals and is measured through 10 items according to previous research (Elbaz, Haddoud, \& Shehawy, 2018; Bute, 2011; Arasli, Bavik,\& Ekiz, 2006; Abdalla, Maghrabi, \& Raggad, 1998).

In this study, the reliability level of the questionnaire is 0.83 (Cronbach's alpha). Here, nepotism refers to the favouritism bias given to family and friends at work (e.g. 'I always feel that I need someone I know or a friend in a high-level position', 'Supervisors are afraid of subordinates related to high-level executives' and 'I am always careful when talking to family or executive relatives').

Job satisfaction is defined as a holistic measure of a person's attitudes and feelings towards work and is measured using a positive version of the Michigan Organizational Assessment Questionnaire Job Satisfaction Scale (Ginsburg et al., 
2016; Bowling \& Hammond, 2008).The results of the analysis report that the reliability level of the questionnaire is 0.74 (Cronbach's alpha). We modified it to give questions, (e.g. 'Overall, I am satisfied with my work', 'In general, I like my work' and 'In general, I like working in this hospital').

OCB is a positive behaviour of employees and does not conflict with organisational systems that can improve the effective functioning of the organisation. The assessment was adopted from previous studies conducted by Ginsburg et al. (2016) and Choi (2007).In this study, we took four items that we modified (e.g.'I often find new ways to do my work', 'My work activities are personally meaningful to me' and 'When my friend seems to need help, I immediately help him'). Based on the analysis results, the level of questionnaire reliability is 0.82 (Cronbach's Alpha).

Organisational commitment is assessed using the Organizational Commitment Questionnaire (OCQ), developed by Allen and Meyer (1990). There are three dimensions of commitment: affective, normative and sustainability commitment. We used six items from all three dimensions:'I would love to spend the rest of my career with this organization', 'It would be very difficult for me to leave this organization properly' and 'I do not believe that one must always be loyal to his organization'. Previous research have also used OCQ (Kim et al., 2019; Cao et al., 2019; Pohl \& Paillé, 2011).The results of the data analysis showthat the level of questionnairereliability was 0.71 (at Cronbach's alpha).

The HRMP variableswere measured based on six main work practices identified by Purcell et al. (2003), namely,career development and opportunities for advancement, training opportunities, job influence and challenges, involvement and communication, performance management and appraisal processes andwork-life balance. We have adjusted 10 questions in accordancewith previous studies that used the same indicators (Sun, Aryee, \& Law, 2007; Wong et al., 2019) (i.e.'There are formal training programmes to teach new employees the skills they need to do their jobs', 'Tasks in this job are clearly defined' and 'Performance is more often measured by objective quantitative results'). The results show that the level of questionnaire reliability was 0.78 (Cronbach's alpha). All indicators of the research variables were measured using a Likert scale $(1=$ strongly disagree, up to $5=$ strongly agree $)$.

\section{Results and Discussion}

Table 1 shows the results of the correlation analysis (Pearson correlation).The results of the analysis show that the independent variable (nepotism) has a positive and strong correlation with all dependent variables (job satisfaction, OCB and organisational commitment) at a significance level $(\mathrm{p}<0.01)$. On the basis of these results, the next analysis can be performed.

Table 1 Correlation, means and standard deviations

\begin{tabular}{lcccc}
\hline \multicolumn{1}{c}{ Variables } & Nepotism & Job satisfaction & OCB & Org.commitment \\
\hline Nepotism & 1 & & & \\
Job satisfaction & $0.534^{* *}$ & 1 & 1 & \\
OCB & $0.493^{* *}$ & $0.597^{* *}$ & $0.486^{* *}$ & 1 \\
Org.commitment & $0.578^{* *}$ & $0.619^{* *}$ & 14.76 & 22.31 \\
Means & 36.81 & 18.47 & 2.583 & 3.574 \\
Standard deviations & 5.650 & 3.148 & 300 & 300 \\
N & 300 & 300 & & \\
$* *$. Correlation is significant at the 0.01 level (two tailed).
\end{tabular}


The results of the MRA,showing the moderating effect of HRMPs on the relationship between nepotism and job satisfaction, are presented in Table 2.The results show that HRMPvariables (interaction) are significant at the 0.05 level. The magnitude of $\mathrm{R}^{2}$ is 0.357 (Table 5), which shows that $35.7 \%$ of the job satisfaction variables can be explained by the variables of nepotism, HRMPs and moderation, whereas the rest $(64.3 \%)$ is influenced by other factors not included in this model. Our results support those of the research conducted by Arasli, Bavik and Ekiz (2006), who also found that HRMPs have a positive effect on job satisfaction and nepotism has a negative effect on job satisfaction. In other words, if an organisation practices HRM well, then the response to job satisfaction will also increase.

Table 2 The Moderating Effect of HRMPs on The Relationship Between Nepotism and Job satisfaction

\begin{tabular}{|c|c|c|c|c|c|c|}
\hline \multirow{2}{*}{\multicolumn{2}{|c|}{ Model }} & \multicolumn{2}{|c|}{ Unstandardised Coefficients } & \multirow{2}{*}{$\begin{array}{c}\begin{array}{c}\text { Standardised } \\
\text { Coefficients }\end{array} \\
\text { Beta }\end{array}$} & \multirow[t]{2}{*}{$\mathbf{t}$} & \multirow[t]{2}{*}{ Sig. } \\
\hline & & $\mathbf{B}$ & Std. Error & & & \\
\hline \multirow{4}{*}{1} & (Constant) & 11.645 & 3.348 & & 3,478 & 0.001 \\
\hline & Nepotism & -0.035 & 0.092 & -0.063 & -0.378 & 0.705 \\
\hline & HRMPs & 0.017 & 0.109 & 0.028 & 0.152 & 0.880 \\
\hline & Nepotism and HRMPs & 0.005 & 0.003 & 0.627 & 2.053 & 0.041 \\
\hline
\end{tabular}

Dependent variable: Job satisfaction

Bold values are statistically significant $(\mathrm{p}<.05)$.

Table 3 shows the results of the analysis on the moderating effect of HRMPs on the relationship between nepotism and OCB. The results of the MRA show that HRMPs have no moderating effect on this relationship. The magnitude of $\mathrm{R}^{2}$ in this relationship is 0.313 (Table 5), which means that $13.3 \%$ of the nepotism factors influence OCB, whereas the rest $(86.7 \%)$ is influenced by other factors outside this model. Basu, Pradhan and Tewari (2017) said that although OCB is not part of a formal organisational structure or reward system, it has broad implications on the performance and effectiveness of organisations and individuals.

Table 3 Moderating Effect of HRMPs on The Relationship Between Nepotism and $\mathrm{OCB}$

\begin{tabular}{|c|c|c|c|c|c|c|}
\hline & \multirow[t]{2}{*}{ Model } & \multicolumn{2}{|c|}{ Unstandardised Coefficients } & \multirow{2}{*}{$\begin{array}{c}\begin{array}{c}\text { Standardised } \\
\text { Coefficients }\end{array} \\
\text { Beta } \\
\end{array}$} & \multirow[t]{2}{*}{$\mathbf{t}$} & \multirow[t]{2}{*}{ Sig. } \\
\hline & & $\mathbf{B}$ & Std. Error & & & \\
\hline \multirow{4}{*}{1} & (Constant) & 6.370 & 2.838 & & 2.244 & 0.026 \\
\hline & Nepotism & 0.034 & 0.078 & 0.075 & 0.438 & 0.662 \\
\hline & HRMPs & 0.131 & 0.093 & 0.272 & 1.411 & 0.159 \\
\hline & Nepotism and HRMPs & 0.002 & 0.002 & 0.231 & 0.732 & 0.465 \\
\hline
\end{tabular}

Table 4 presentsthe MRA resultson the moderatingeffects of HRMPs on the relationship between nepotism and organisational commitment. The analysis shows that HRMPs are variables that moderate the relationship, with a significance value of 0.039( $\mathrm{p}<0.05$ ). Thus, HRMPs are significant as moderation variables and can be categorised as pure moderation. In addition, the results of the coefficient of determination test (Table 5) show an $\mathrm{R}^{2}$ value of 0.383 (38.3\%), meaning that $38.3 \%$ of the nepotism variables affect the variation in terms oforganisational commitment, whereas the rest $(61.7 \%)$ is influenced by other variables not examined here. 
Table 4 Moderating Effect of HRMPs on The Relationship Between Nepotism and Organisational Commitment

\begin{tabular}{llccccc}
\hline \multirow{2}{*}{ Model } & \multicolumn{2}{c}{ Unstandardised Coefficients } & $\begin{array}{c}\text { Standardised } \\
\text { Coefficients }\end{array}$ & t & Sig. \\
\cline { 2 - 5 } \multicolumn{1}{c}{ (Constant) } & B & Std. Error & Beta & & \\
\hline \multirow{2}{*}{1} & 13.974 & 3.722 & & 3.754 & 0.000 \\
& Nepotism & 0.027 & 0.103 & 0.043 & 0.266 & 0.790 \\
& HRMPs & -0.029 & 0.121 & -0.044 & -0.240 & 0.810 \\
& Nepotism and HRMPs & 0.006 & 0.003 & 0.620 & 2.071 & $\mathbf{0 . 0 3 9}$ \\
\hline
\end{tabular}

Dependent variable: Organisational commitment

Bold values are statistically significant $(\mathrm{p}<.05)$.

Table 5 presents the test results for the coefficient of determination of the direct and moderating effects. The results showthat the strengths of the direct influence of nepotism variables on job satisfaction, OCB and organisational commitment are $28.5 \%, 24.3 \%$ and $33.4 \%$ and the strengths of the moderating effect of HRMPs are $35.7 \%, 31.3 \%$ and $38.3 \%$, respectively. Thus, the HRMP variable moderates the three dependent variables (job satisfaction, OCB and organisational commitment) because there is an increase in the effect strength of the nepotism variable after the variable moderation.However, there is no significant moderatingeffecton the relationship between nepotism and OCB.

Table 5 Summary of Test Results For The Coefficient of Determination (Direct and Moderating Effects)

\begin{tabular}{|c|c|c|c|}
\hline \multicolumn{2}{|r|}{ Variable Effect } & Direct Effect & Moderating Effect \\
\hline Nepotism & Job satisfaction & 0.285 & 0.357 \\
\hline Nepotism & $\rightarrow \quad \mathrm{OCB}$ & 0.243 & 0.313 \\
\hline Nepotism & $\rightarrow$ Organisationalcommitment & 0.334 & 0.383 \\
\hline
\end{tabular}

\section{Conclusion}

In this study, we formulatedthreehypotheses.Accordingly, we can conclude that, firstly,HRMPs have a moderating effect on the relationship between nepotism and job satisfaction. This moderation is pure moderation because there is no direct effect between nepotism and HRMPs on job satisfaction. Secondly, HRMPs have no moderating effect on the relationship between nepotism and OCB. Third, HRMPs have a moderating effect on the relationship between nepotism and organisational commitment.

The limitation of our study is that the nepotism variable predicts only three components of attitude (job satisfaction, OCB and organisational commitment). For future research, it is necessary to predict other attitude elements that have a potential impact on nepotism(e.g. emotional intelligence, individual decision making, deviant workplace behaviour). Variable moderation can also be used by other relevant variables.

\section{References}

Abdalla, F.H., Maghrabi, S., \& Raggad, G. B. (1998). Assessing the effect of nepotism on human resource managers toward nepotism a cross cultural study. International Journal of Manpower, 19(8), 554-70. 
Allen, N., \& Meyer, J. (1990). The measurement and antecedents of affective, normative and continuance commitment to the organization. Journal of Occupational Psychology, 63, 1-18.

Arasli, H., Bavik, A., \& Ekiz, E. H. (2006). The effects of nepotism on human resource management: The case of three, four and five star hotels in Northern Cyprus. International Journal of Sociology and Social Policy, 26 (7/8), 295-308.

Basu, E., Pradhan, R. K., \& Tewari, H. R. (2017). Impact of organizational citizenship behavior on job performance in Indian healthcare industries: The mediating role of social capital. International Journal of Productivity and Performance Management, 66(6),780-796.

Billet, S. (2009). Relational interdependence between social and individual agency in work and working life. Mind, Culture, and Activity, 13(1), 53-69.

Bowling, N. A., \& Hammond, G. D. (2008). A meta-analytic examination of the construct validity of the Michigan Organizational Assessment Questionnaire Job Satisfaction Subscale. Journal of Vocational Behavior, 73, 63-77.

Brenner, B. R., Lyons, H. Z., \& Fassinger, R. E. (2010). Can heterosexism harm organizations? Predicting the perceived organizational citizenship behaviors of gay and lesbian employees. Career Development Quarterly, 58(4), 321-335.

Büte, M. (2011). The Effects of Nepotism and Favoritism on Employee Behaviors and Human Resources Practices: A Research on Turkish Public Banks. TODAĐE's Review of Public Administration, 5(1), 185-208.

Cao, Y., Liu, J., Liu, K., Yang, M., \& Liu, Y. (2019). The mediating role of organizational commitment between callingand work engagement of nurses: A cross-sectional study. International Journal of Nursing Sciences, 6, 309-314.

Choi, J. N. (2007). Change-oriented organizational citizenship behavior: effects of work environment characteristics and intervening psychological processes. Journal of Organizational Behavior, 28, 467-484.

Cohen, J., Cohen, P. West, S. G., \& Aiken, L. S. (2003). Applied Multiple Regression/ correlation Analysis for the Sciences, 3th ed., Mahwah, New Jersey, London, Lawrence Erlbaum Associates.

Elbaz, A. M., Haddoud, M. Y., \&Shehawy, Y. M. (2018). Nepotism, employees' competencies and firm performance in the tourism sector: A dual multivariate and Qualitative Comparative Analysis approach. Tourism Management,67, 3-16.

Findıklı, M. A., Yozgat, U., \& Rofcanin, Y. (2015). Examining Organizational Innovation and Knowledge Management Capacity The Central Role of Strategic Human Resources Practices (SHRPs). (3rd International Conference on Leadership, Technology and Innovation Management). Procedia - Social and Behavioral Sciences, 181, 377-387.

Foote, D. A., \& Li-Ping Tang, T. (2008). Job satisfaction and organizational citizenship behavior (OCB): Does team commitment make a difference in self-directed teams?, Management Decision, 46(6), 933-947.

Ginsburg, L. et al. (2016). Measuring Work Engagement, Psychological Empowerment, and Organizational Citizenship Behavior Among Health Care Aides. Gerontologist, 56(2), 1-11.

Hambrick, D. C., \& Mason, P. A. (1984). Upper echelons: The organization as a reflection of its top managers. Academy of Management Review, 9, 193-206. 
Hayajenh, A. F., Maghrabi, A.S,. \& Al-Dabbagh, T. H. (1994). Research Note: Assessing the Effect of Nepotism on Human Resource Managers. International Journal of Manpower, 15(1), 60-67.

Hudson,S.,\& Claasen, C. (2017). Nepotism and Cronyism as a Cultural Phenomenon? In The Handbook of Business and Corruption. 95-118.

Jaskiewicz, P., \& Luchak, A. A. (2013). Explaining performance differences between family firms with family and nonfamily CEOs: It's the nature of the tie to the family that counts!Entrepreneurship Theory and Practice, 37, 1361-1367.

Kim, M. Ja., Bonn, M., Lee, Choong-Ki , \& Jinok Susanna Kim. (2019). Effects of employees' personality and attachment on job flow experience relevant to organizational commitment and consumer oriented behavior. Journal of Hospitality and Tourism Management, 41, 156-170.

Lubatkin, M. H., Schulze, W. S., Ling, Y., \& Dino, R. N. (2005). The effects of parental altruism on the governance of family-managed firms. Journal of Organizational Behavior, 26(3), 313-330.

Luthans, F. (2011). Organizational Behavior: An Evidence-Based Approach. 12th ed, Avenue of the Americas, New York. McGraw-Hill/Irwin.

Malik, A. (2018). Nepotism is bad for the economy but most people underestimate it. The Conversation. https://theconversation.com/nepotism-is-bad-for-theeconomy-but-most-people-underestimate-it-103909. (accessed 3131 January 2020).

Meyer, J.P., \& Allen, N.J. (1984). Testing the 'side-bet theory' of organizational commitment: some methodological considerations. Journal of Applied Psychology, 3, 373-378.

Mondy, R. W., \& Martocchio, J. J. (2016). Human Resource Management, 14Th Ed. Edinburgh Gate, Harlow, Essex CM 20 2JE, England, Pearson Education Limited.

Nickson, D. (2013). Human resource management for hospitality, tourism and events (2nd ed.). New York, USA: Routledge. Organizational Behavior. 15th ed., One Lake Street, Upper Saddle River, New Jersey 07458, Pearson Education, Inc.

Podsakoff, P.M., MacKenzie, S.B., Paine, J.B., \& Bachrach, D.G. (2000). Organizational citizenship behaviors: a critical review of the theoretical and empirical literature and suggestions for future research. Journal of Management, 26(3), 513-563.

Pohl, S., \& Paillé, P. (2011). The impact of perceived organizational commitment and leader commitment on organizational citizenship behaviour. International Journal of Organization Theory \& Behavior, 14(2), 145-161.

Purcell, J., Kinnie, N., Hutchinson, S., Rayton, B., \& Swart, J. (2003). Understanding the People and Performance Link: Unlocking the Black Box. London, U. K.: Chartered Institute of Personnel and Development.

Reid, R., Morrow, T., Kelly, B. \& Cartan, M.P. (2002). People management in SMES: an analysis of human resource strategies in family and non-family businesses. Journal of Small Business and Enterprise Development, 9(3), 245-59.

Robbins, S. P., \& Judge, T. A. (2013). Organizational Behavior, 15th Ed. Upper Saddle River, New Jersey, Pearson Education, Inc. 
Sarpong, D., \& Maclean, M. (2015). Service nepotism in the multi-ethnic marketplace: mentalities and motivations. International Marketing Review, 32(2), 160-180.

Shafazawana., Tarikh, M., Ying, C. Y., Zuliawati., Saad, M., \& Sukumaran, K. (2016). Managing Job Attitudes: The Roles of Job Satisfaction and Organizational Commitment on Organizational Citizenship Behaviors. Procedia Economics and Finance, 3, 604-611.

Sharma, S., Durand, R. M., \& Gur-Arie, O. (1981). Identification and analysis of moderator variables. Journal of Marketing Research, 18, 291-300.

Stewart, A. (2003). Help one another, use one another: toward anthropology of family business. Entrepreneurship, Theory and Practice, 27(4), 383-396.

Sun, L.-Y., Aryee, S., \& Law, K. S. (2007). High-performance human resource practices, citizenship behavior, and organizational performance: A relational perspective. Academy of Management Journal, 50(3), 558-577.

Tsaur, H., \& Lin, C.Y. (2002). Promoting service quality in tourist hotels: the role of HRM practices and service behavior. Tourism Management, 25(1), 471-81.

Xie, B., Zhou, W., Huang, J. L., \& Xia, M. (2017). Using goal facilitation theory to explain the relationships between calling and organization-directed citizenship behavior and job satisfaction. Journal of Vocational Behavior, 100, 78-87. 